\title{
EVOLUTION OF HUMAN RIGHTS EDUCATION IN INDIA: AN EVALUATION
}

\author{
Dr. Hitesh Ch. Kalita \\ HOD \&Associate Professor in Philosophy \\ MNC Balika Mahavidyalaya, Nalbari, Assam, India
}

\begin{abstract}
The paper proposes to present and elaborate and critically analyze the main concepts of 'evolution of human rights education in India' with an evaluation. The concept of human rights means that everybody has the right to freedom of thought, conscience and religion; this right includes freedom to change his religion or belief, and freedom, either alone or in community with others and in public or private, to manifest his religion or belief in teaching, practice, worship and observance.
\end{abstract}

Cite this Article: Dr. Hitesh Ch. Kalita, Evolution of Human Rights Education in India: An Evaluation, Journal of Management, 6(3), 2019, pp. 150-153.

http://www.iaeme.com/jom/issues.asp?JType=JOM\&VType=6\&IType=3

\section{INTRODUCTION}

Though Universal Declaration on Human Rights took place on $10^{\text {th }}$ December 1948 to the charter of O.N.O. but it is not a new phenomena in India. The basis of it in India is 'Dharma'. Veda, Mahabharata and history of India tried to keep in human rights.

\section{METHODOLOGY}

It has been mainly used by empirical and rational. Moreover, following philosophical studies of its secondary data it is mainly helped by television, newspaper, book, journal, research paper, internet (web resources) and discussion of the people related to the issue.

\section{OBJECTIVE}

- The main objectives are to be stated as following:

- To study the main concept of Human rights education.

- To study the evolution of human rights education in India.

- To study the need of it in education system. 


\section{RESULT AND DISCUSSION: HUMAN RIGHTS EDUCATION AND INDIA}

It is known to all that everybody tries to get goal or emancipation of own life, such as highest pleasure, equal dignity with other sex, freedom of will etc. This goal can't be possible without keeping in rights of human life. The study took a formal shape in recent times getting popularity world over. The term 'human rights' was first used by Franklin Roosvelt and secondly used in the Atlantic Charter. The same view was repeated shortly in the Declaration of the United Nations signed on 1 January 1942. The concrete form of the Declaration was December 1948

The concept of human rights in India is not new. In India, over two thousand years ago, "Kautilaya in his famous and immortal work, 'Arthashastra' defined human rights of war prisoners"1. In the landmark decision of Maneka Gandhi vs Union of India, Justice Bhagawati, J., speaking about the importance, observed, "these rights represent the basic values cherised by the people of this country (India) since the Vedic times and they are calculated to protect the dignity of the individual and create conditions in which every human being can develop his personality to the fullest extent. They weave a pattern of guarantee on the basic structures of human rights and impose negative obligations on the state not to encroach on individual liberty in its various dimensions." 2 Indian emperors like Ashoka and Akbar concerned for the people and their welfare can hardly be over emphasized. The Tamil epic "Tirukkural" also explained about the inherent civil, political, economic, social and cultural rights of individual. In the sixth Century B.C. Buddhism and Jainism stated the principles of equality, non-violence and denial of materialistic pleasures also reflct human rights education which hit out at very roots of caste system of ancient India.

Education is one of the important ways to teach the fundamental activities of human race. So, Socrates said, "know thyself and be thyself"3 is the universally acknowledged aim of education. Education has a basic relation with the concept of human rights. Human soul is the basic point of education and human rights.

Human beings are only rational beings. They following virtue possess certain and necessary rights which are known as human rights. So, "human rights, being the birth-right, are, therefore, inherent in all the individuals irrespective of their caste, creed, religion, sex and nationality."4 Similarly, the World Conference on Human Rights held in 1993 in Vienna stated in the Declaration that, "all human rights derive from the dignity and worth inherent in the human person and that the human person is the central subject of human rights and fundamental freedoms." "In this reference, Socratic soul's virtue of human being is in human rights. These rights are accompanied by human self's existence. So, the founder of existentialist J.P. Sartre said that man's pure inner self-existent is fully free from any bondage, exploitation, attack, fear etc.

India manifested in the form of demand for fundamental freedoms and civil and political rights for the people when India was under British control. India's freedom struggle in historical perspective is also found to be a struggle for human rights. Probably in 1895 the-Swaraj Bill was inspired by B.G.Tilak. Tilak in his famous Gita Rahasya said that swaraj or self-rule is birth right. Then, Indian National Congress in the Delhi session of December included the principles of self-determination in the basic rights of human being. 
The common nature of human rights education is tried to establish through the following famous views.

- According to Article 18 of the International Covenant on Civil and Political Rights, "Everyone shall have the right to freedom of thought, conscience and religion."

- According to Article 8 of the African Charter on Human and Peoples' Rights, "Freedom of conscience religion." ${ }^{\prime 7}$

- According to Article 12 of the American Convention on Human Rights, “...freedom of conscience and religion. ${ }^{8}$

- According to Article 9 of the European Convention on Human Rights, "Freedom of thought, conscience and religion. ${ }^{9}$

These rights are actually known to self-realised person. Myself can only know my real rights. Self-determination is one of the important qualities of human rights. Our rights are not unlimited. They are determined by our self. Self's rights are in favour of social welfare. It equally comes from each individual from within. Deep study following philosophy is necessary to acquire it. These rights should not be violated by anything or anyone. In this sense it includes, "the right to self-determination of peoples rather than individuals, to sovereignty over their country's natural wealth, and to development and special protection of disadvantaged groups. ${ }^{\mathbf{1 0}}$. It is very important that every self-realised person knows what his rights. He has no real development without knowing real right.

Government must control over man's action for keeping human rights. National or international laws should be used to protect men in the interest of the humanity. But it is most important that a man's rights cannot be protected by out sides such as government, international laws, NGO, etc. if he is not self-realised and self-determined. For self-realisation, human rights education is necessary.

Indian government constituted the National Human Rights Commission on $28^{\text {th }}$ Sept. 1993 , which has been taking all out efforts in fulfilling the obligations entrusted to it under the Section 12(h) of the Protection of Human Rights Act, 1993 for developing human rights education and awareness. In this direction, the Commission has taken an effort to develop it through the U.G.C. in the year 1999. U.G.C. starts in the year in various universities and colleges. Human Rights Eduaction following UGC in the year 2001 introduced and developed the model on human rights in various colleges and universities. The model was followed from the perspective of the changing global scenario. Then, the Commission at first collected the syllabus of human rights education being taught at different colleges and universities across the nation. It is found that a limited number have introduced human rights.

National Human Rights Commission at present recommends for getting human rights such as:

"Under-graduate Foundation Course on Human Rights.

Certificate Course on Human Rights.

Under Graduate Degree Course on Human Rights.

Post Graduate Foundation Course on Human Rights.

Post Graduate Diploma Course on Human Rights.

Post Graduate Degree Course on Human Rights.

Post Graduate Degree Optional Courses on Human Rights.

Identification of the New Areas for Research in the field of Human Rights."11 


\section{CONCLUSION}

Human rights are actually positive bliss. So the main concept of human rights should be taught to all people of India through various ways before giving importance on protection and exploitation. Teachers training should be done through regular workshops and seminar conducted with the help of research persons from various corners observing real development of human being. All departments of colleges and universities should be based with the basic concept of human rights. The departments should know that their knowledge is blind without knowledge of human rights. So it should be actualized from the stage of pre-primary, primary and school to colleges and universities. In this reference, the course of human rights should be introduced in pre-primary, primary and high school. As soon as the concept of philosophy should be taught to all people for getting knowledge of human rights. The main substance of human rights is soul-based.

\section{REFERENCE}

1. Paul. J. I, \& Sinha, M.K., Human Rights and Global Governance. p.211

2. Ibid, p. 210

3. Dutta, D.M. Chief Currents of Contemporary Philosophy, p.513

4. Agarwal, Dr. H.O, Human Rights, p.2

5. Ibid, p.2

6-9. Mishra, Jyotsna, Scope and Categories of Human Rights, 2-3,12\&10

10. Bhargava, Gopal, Human Rights, p.54

11. www.google.comHuman Rights in Colleges and Universities/pdf. 